Discourse and Communication for Sustainable Education, vol. 7, no. 1, pp. 49-67, 2016

\title{
Using Photovoice to Explore Environmental Sustainability Across Languages and Cultures
}

\author{
Kristin Cook \\ Bellarmine University, USA \\ Alan Brown \\ University of Kentucky, USA \\ Genny Ballard \\ Centre College, USA
}

\begin{abstract}
Though work in the area of photovoice (in which students take photos to structure a dialogue that can serve to advance social action as the community responds to the participants' perspectives and locates them in solution-generation) has been conducted in science education research to focus on learner's experiences, little has been done to showcase community members' perspectives resulting from the photovoice experiencethough it is here that photovoice holds the most potential to effect positive change locally. The research presented here, conducted during a study abroad course taught in Costa Rica, seeks to understand the ways in which the experience of photovoice stimulated an understanding of and connection to local sustainability issues and to those for whom these issues are most pressing. The study involves a cross-cultural and cross-linguistic exchange of ideas regarding sustainable crop development between study abroad students and community members in a rural mountain town in Costa Rica. Results indicated that the experience of photovoice broadened and enriched all participants' understanding of environmental sustainability-university students and local residents-as well as inspired critique of socio-scientific issues of personal relevance and impact. Photovoice is thus presented as a rich and engaging instructional technique that also serves as a community participation tool with potential for connecting students and communities from distinct cultures and languages.
\end{abstract}

Keywords: study abroad, environmental sustainability, photovoice, college science teaching

The quest for inclusive approaches of soliciting student participation in community science is nestled in a broader community-based participatory movement in science education that investigates socio-scientific issues by collaborating with those affected by the issue with the goal of increasing awareness and taking action. Such approaches have included variations on community-based and place-based inquiry (Calabrese, Barton, 
2003) and ecojustice curricula (Tippins \& Mueller, 2010) focusing on complex socioscientific issues (Zeidler, Sadler, Simmons, \& Howes, 2005) to empower learners of science to deepen their connection to science content (Hodson, 2003; Roth \& Lee, 2004; Bencze et al., 2009). Such aims seek to create an opportunity for students to become participants in the community through the exploration of science. Student empowerment is the central aim of these curricula and echo Paulo Freire's (1970) model of learning: start from problems in the community, use active learning methods, and engage participants in determining their own needs and priorities in solving the problem.

Research in science education has emphasized the importance of connecting learners to place (Chinn, 2007), regardless of whether that place is culturally and linguistically familiar to students or one in which they live. Place-based education brings the classroom into the community and the community into the classroom (Sobel, 2005). Multiple studies have shown that connecting students to place increases academic achievement, helps students develop stronger ties to the community, enhances students' appreciation for the natural world, and creates a heightened commitment to serving as contributing citizens (Gruenewald \& Smith, 2008). Efforts focused on place have found that learning science in this context provides teachers' with both the rationale and agency to restructure their curricula towards field-based science learning and enhances participation of learners by connecting science knowledge with issues relevant to their own lives and communities (Chinn, 2007). This connection to place is especially important for students, who may be disconnected from direct sources of food or for whom energy or water usage does not have visible consequences, may be unaware of the impacts of their consumer choices on the larger ecosystem, and for whom access to natural ecosystems may be limited. The disconnect between students and the environment may be exacerbated when placed in an ecosystem completely foreign to them that is populated by individuals whose culture and language differ from their own.

However, while rhetoric in the science education community posits lofty goals for the study of socio-scientific issues through place-based curricula such as citizenship education, enhancing students' connections to science, and empowering students for the betterment of society (Sadler, Barab, \& Scott, 2007), little research has been done to fully investigate these potentials. Furthermore, critics of place-based education assert it is not enough to focus merely on one's own place (Nespor, 2008). In fact, because place is influenced by so many outside forces, limiting one's view to their immediate settings has the potential to inhibit a full examination of the factors shaping the environment. For example, testing water quality in the schoolyard creek without an investigation into the sociopolitical and socioeconomic elements that impact waste management and industrial regulations limits one's view of the environment. Instead, it can produce what has been referred to as the 'luxury of obliviousness,' where one has "the freedom to live unaware of what you're participating in and how and with what effect” (Johnston, 2008, p. 180).

This study aimed to investigate the potential of a promising participatory action tool termed photovoice, which has received attention in public health education and community development and more recently in science education (Powers \& Freedman, 2012; Cook \& Buck, 2010; Cook \& Quigley, 2013; Cook, 2014), to connect science learners and community members in examining and critiquing local environmental issues and the complex factors shaping them. In the process of photovoice, students take photographs of the community, and those photos offer structure to dialogue that can serve to advance social action as the community responds to the participants' perspectives 
and locates them in solution-generation. In our own work using photovoice as a research and teaching tool, the process has shown to be impactful in the bridging of learners' backgrounds and interests with environmental science topics of importance to the community. As well, because photovoice community events specifically invite people connected to the topic under study, the dialogue enables learners to communicate with those in a position of knowledge-and in some cases - control over the issue in a way that democratizes the dialogue, it inspires a deepened sense of care and interest in contributing to the community of science (Cook \& Quigley, 2013). However, while the focus on learners is indeed important, the emphasis on the community dialogue resulting from photovoice is an area of untapped potential deserving of deeper exploration. Because our own and others' work in the area of photovoice has been conducted to focus on learners' experiences, little has been done to showcase community perspectives resulting from the photovoice experience-though it is here that photovoice holds the most potential impact with regard to broadening awareness and critiquing local issues from the vantage point of multiple perspectives. Because we wished to investigate the ways in which photovoice could stimulate a deep and multifaceted exploration of complex issues in a community, this study involved a cross-cultural and cross-linguistic exchange of ideas between students and community members concerning sustainable crop development-an area of considerable debate and local investment. The following research question guided this study: In what ways does photovoice broaden participants' awareness and cross-cultural understanding of environment sustainability?

\section{Theoretical Framework}

Grounded in a socio-cultural view of learning and a critical approach to education, the use of participatory methods requires re-conceptualizing science knowledge, science practitioners, and science education, as well as moving from a focus on individual possession of knowledge toward public, distributed knowledge embedded in particular places and in matters of local concern (Fisher, et al., 2015). Thus, learning science becomes an avenue for social action that emerges in terms of a particular issue and represents both personal and collective interests (Brunold, 2015). This study, which aims to investigate the potential of photovoice to bring about reflective deliberation, draws upon critical theory to create an experience of learning science that enables students and local community members to engage with one another for mutual benefit.

Photovoice has roots in critical theory by attempting to make explicit insider's perspectives and critically reflect on them for the betterment of society through the use of dialogue. Students take photographs of the community, and those photos offer a structure to a dialogue that can serve to advance social action as the community responds to the participants' perspectives and locates them in solution-generation. Thus, we endeavored to improve the lives of our participants by supporting their notions of agency in being part of the science that operates in their community. As a critical theorist, Jürgen Habermas' idea of communicative action (1984) underscores the value of dialogue in scientific understanding and advancement. The tool of photovoice aligns with Habermas' notions about the importance of multiple voices and perspectives in scientific knowledge. In our study, students investigated the environmental issue of sustainable crop development, which involved complex negotiation beyond the scientific sphere to the political, economic, and social spheres. 


\section{Synthesis of Related Literature}

Photovoice enables learners to document issues important to them through the use of photography to generate dialogue with key community members who may be in a position to mobilize change (Wang \& Burris, 1994; Wang, 2005). As opposed to other photo-elicitation techniques, photovoice uniquely incorporates dialogue between students and knowledgeable community members as an important step in allowing for a deepened understanding of the issue and potential for impact. The process begins with the recording of and reflecting on problems of a group or community and follows with the critical discussion of these problems and generation of collective knowledge of the problems through discussion of the photographs. The ultimate goal is finally to take action to change the problems by reaching out to those who influence or make policy (Wang, 2005). In doing so, photovoice empowers participants to more fully engage in critical dialogue about issues facing a community.

Photovoice has been used in public health education and community development to connect participants to the community in an effort to inspire change in various cultures. A study by Morgan et al. (2010) explored female Nicaraguan immigrants in rural Costa Rica through photovoice aiming to document, critique, and ultimately to improve life conditions for these residents. Findings indicated "the process empowered these women by affirming their community strengths and providing them with an avenue, through photographs and stories, for voicing their needs to policymakers and community leaders" (p. 1). Used here among marginalized immigrants, photovoice provided insight into how they conceptualize their circumstances and hopes for the future. While the researchers codified themes from the women's narratives and identified areas of need, researchers lamented that a community forum did not transpire in the village and the important stories were not heard by those with power to impact change on a larger scale. As scholars from the field of critical discourse analysis have noted, language and power are intricately intertwined (Fairclough, 2001). When underprivileged and marginalized populations are given a voice and granted legitimate access to key discourses, the result can be quite empowering while also serving as a crucial vehicle for identity construction. In Morgan et al. (2010), photovoice seems to have served these very functions for community members.

Similarly, Quigley et al.'s (2014) work in Kenya speaks to the importance of decolonizing methodologies to bring forth voices of those impacted by and coping with the decisions of others regarding the environmental policies and management of their communal resources. Attempting to expand the dialogue between Western science and indigenous knowledge, their study illuminates questions regarding the impact of such methodologies on the participants as well as the community of science at large. Quigley et al.'s use of photovoice has a noble aim in seeking to improve participants' lives while also informing the field of science education about how to structure curricular reform efforts to be inclusive and impactful; however, their project focused only on phase of an ongoing and multistep research project (the next phase of which will highlight the focus group interviews to develop emergent and co-constructed understanding of the key environmental terms), so the foundations for active engagement of the participants within the community of science were laid but not yet realized. Such aims will require a much-needed dialogue among citizens, science educators, and those with institutional power to more directly affect policy. 
In Bennett and Deadon's (2013) work in coastal Thai communities, we see the effects of engaging the community as part of the photovoice project. After compiling participants' narratives and photographs of environmental change, researchers structured public forums, workshops, and even a publication of a book that was given to schools and village chiefs to discuss environmental and social trends as well as ecological specifics and social particularities in several locations along the coast of Thailand. Researchers found that community outreach positively enhanced awareness, consolidated disparate bits of knowledge, and led to shared understandings among members of the community.

Additionally, Downey et al. (2009) used photovoice to explore rural Appalachia residents' understanding of and barriers to public health in an effort to improve the access to resources in the community. Researchers found that although debate was an important part of the experience with photovoice, the opportunities to deliberate with the community empowered participants as active members in the community. In fact, researchers concluded that the process of using images and personal narratives to inspire dialogue led to more specific and detailed ideas on reform than other types of community dialogue.

Exploring the connection of well-being to ecosystem services, Marta Berbés-Blázquez (2012) also emphasized the importance of community dialogue in critiquing and improving environmental management plans. Set in Costa Rica's pineapple industry, her work showed how the use of photovoice was instrumental in understanding what was important to people and how environmental services could help support well-being in the community. She concluded that the information gleaned in the community deliberation "integrated the knowledge of diverse stakeholders, recognized power imbalances, and [led to] grappling with the complexity of social-ecological systems" (p. 862).

In authors' own work using photovoice with college students and scientists, they have found that it leads to a deepened understanding of the science embedded in daily lives and inspires a sense of care for the environment (Cook \& Quigley, 2013). Also, because the experience of communicating about their views with those who often know more about or have had more experience with the issue, students come to appreciate the multiple viewpoints and perspectives surrounding environmental considerations. Students often feel inspired to take action and educate others about what they have experienced through photovoice (Cook, 2014).

In effect, photovoice offers a tool for science educators at a time when a case is being made for scientifically literate citizens to possess the ability to assess the value of and critically evaluate knowledge in a particular context and to participate in the social negotiations that produce knowledge (Roth \& Lee, 2004). In particular, photovoice has been used to explore environmental conditions and issues, which often lie at a nexus point of science and society-offering a platform for participant involvement in policies that directly impact their lives and surroundings. It is here, within the exploration of environmental sustainability, that citizens can begin to critique as well as participate in socio-scientific issues of personal relevance and impact.

As seen in the above examples, the use of photography offers participants new and reflective ways to perceive their own world and offered researchers new insights and perspectives. Beyond that, the community dialogue component of the photovoice process enables the dissection and critique of local issues leading to ideas for specific resolutions. Used in this study to explore sustainable crop development in a tropical agricultural community, photovoice enables learners to dialogue with those most affected by the issue and critique the complex factors shaping the issue in the community. 


\section{Methodology}

In an effort to explore the ways in which the experience of photovoice broadens participants' awareness and cross-cultural/cross-linguistic understanding of environment sustainability, the authors conducted a case study in Costa Rica with study abroad students and community members of a rural mountain town. Because coffee growing was the primary industry in the town, there was much interest in environmental management and sustainable practices of coffee cultivation and exportation.

\section{Context \& Participants}

The photovoice project was part of a study abroad course for education and health sciences majors entitled Environmental Sustainability: Lessons from a Leader. The principle objective of this course was to provide undergraduate students with firsthand experience to develop a better comprehension of the challenges and opportunities for environmental conservation and sustainable livelihoods in tropical ecosystems. Field activities were designed to bring students face to face with the richness of tropical ecosystems, with the diversity of ways humans interact with these ecosystems, and with an array of visions and definitions about development and sustainability — giving students a more profound, informed and sophisticated understanding of these issues as well as the opportunity to critically analyze and develop a nuanced understanding of the complexity involved in the development, promotion, and maintenance of sustainability. The course was conducted in the community of San Marcos, a rural mountain town in Costa Rica 70 kilometers south of the national capital city of San José. Farmers started growing coffee in this highland valley in the 1890s. In this mountainous terrain, coffee growing is ideal due to the high altitude and rich volcanic soil as well as the mountains facing the morning light and the cloud cover protecting the coffee trees in the afternoon. Cultural and economic progress in San Marcos has traditionally been directly tied to the coffee industry.

During this 6-week summer course, eight students studied the factors shaping Costa Rica's leadership in coffee production by examining the historical, environmental, and political aspects that influence the valuable export crop. During these explorations in the mountain town of San Marcos (known as Costa Rica's premier coffee growing center), students visited several coffee plantations, production facilities, and even lived in home stays with people who work in various capacities within the coffee production sector. Locally debated issues such as the benefits/costs of fair trade, migrant worker equity, and sustainable agriculture arose as students learned about how coffee is produced and exported to the rest of the world.

As the culmination of the coffee field trips and explorations, a photovoice event was held on a weekend in which all people with whom students had interfaced during their exploration of coffee in San Marcos were invited to participate. In total, approximately 60 people were in attendance ranging from coffee growers to production managers to coffee consumers. A key contribution to this encounter was made by fellow study abroad students enrolled in an introductory translation class. Although a few of the sustainability students had achieved some proficiency in Spanish, others had no functional proficiency in Spanish and would not have been able to engage with the monolingual Spanish-speaking community members without assistance. As part of their course, the translation students partnered one to one with the Environmental Sustainability students 
to facilitate conversations in Spanish among the participants. Students in the Environmental Sustainability class $(\mathrm{N}=8)$ were asked to take photographs and write narratives about the issues they had been exploring in class, and the Spanish Translation students $(\mathrm{N}=8)$ assisted them in translating those narratives prior to the community event. On the day of the event the Spanish Translation students provided consecutive interpretation for the Environmental Sustainability students as they interacted with community members. During the dialogue event, the Costa Rican attendees moved around the room visiting with each student pair, listening/reading their translated narratives, and discussing the issues with them from their perspectives.

After the event, students (both from the environmental science class and from the translation class) were asked to write reflections of the experience in their journals. The Costa Rican participants were also asked to briefly describe their experience in the photovoice event as well (see Appendix A attached for examples in which attendees were asked to describe their relationship with coffee and comment on each of the photovoice narratives).

\section{Photovoice Process}

After basic training on using the cameras (i.e. manual operation skills and considerations on lighting, distance, and picture composition), students were asked to take photographs that showcased "sustainable coffee development" and write semi-structured narratives (see Cook, 2014 for complete set of instructional prompts, which included: what is interesting or important about this issue; who is affected by this issue; and what does the future look like for this issue?) about what they perceived to be important from what they had been learning in class and experiencing in the field. Although they had taken several photographs throughout their field experience, students were asked to choose one that best depicted the issues they thought most needed consideration in a community forum.

The instructors' role in photovoice is to facilitate conversation, storytelling, and reflection on pictures taken by the participants, and then attempt to codify the emergent themes that are generated by collective discussion (Wang, 2005). As a group, the class discussed overarching themes that constituted a thread throughout their narratives before presenting to the community. Through this discussion, each group found that certain common issues or themes emerged. Identification of common themes led the student group to come up with main ideas or messages that they collectively wanted to communicate to the community (these included an acknowledgement of sustainable practices, constraints on ecological management, and social constituents in coffee production). After collective discussion, students attended a local community event to dialogue with informed community members about their perspectives on the issues. Attendees from the community included coffee growers, production managers, and coffee consumers (see Table 1 for description of community members).

The students held their pictures and narratives, which had been translated into Spanish for the gallery walk event as mentioned previously, as an aid with which to discuss their topics with attendees. Attendees moved from table to table meeting and talking with each student pair (one science and one translation student) about their photos and narratives. 
Table 1

Information about Community Participants

\begin{tabular}{lll}
$\begin{array}{c}\text { * } \begin{array}{c}\text { Name } \\
\text { pseudonyms } \\
\text { given }\end{array} \\
\text { Juan }\end{array}$ & Age & \multicolumn{1}{c}{ Self-described Relationship to Coffee } \\
\hline Luis & 50 years & I am a coffee grower and an associate of the cooperative. \\
\hline Clau & $\begin{array}{l}\text { No direct relationship; nevertheless, I know people who work in } \\
\text { and grow coffee and I know that it is daily hard work. }\end{array}$ \\
\hline Natalia & 22 years & $\begin{array}{l}\text { Owner and associate. } \\
\text { a relationship with this product since I had to accompany my father } \\
\text { to pick coffee. Now, I do not pick it but it is my favorite drink. }\end{array}$ \\
\hline Rosa & 35 years & $\begin{array}{l}\text { We are owners of coffee farms. I have a very close relationship with } \\
\text { the coffee crop because with my husband, we are in charge of the } \\
\text { maintenance. }\end{array}$ \\
\hline Yazmin & 36 years & $\begin{array}{l}\text { The relationship is very hit and miss for my mom and me. My kids } \\
\text { drink it, but very little. }\end{array}$ \\
\hline Alexa & 33 years & $\begin{array}{l}\text { In my family, we work in the production of coffee and we enjoy it } \\
\text { for our own consumption besides being a source of work in this area. }\end{array}$ \\
\hline Ana & 29 years & $\begin{array}{l}\text { My relationship with coffee: we are coffee growers. It is our source } \\
\text { of income and we are associates of the co-op. }\end{array}$ \\
\hline Levi & 60 years & $\begin{array}{l}\text { Previously, there was a direct relationship in the processing of } \\
\text { coffee since I was an authority or official at the co-op. Now, we } \\
\text { are just consumers. }\end{array}$ \\
\hline Alonso & 51 years & $\begin{array}{l}\text { In this area, we have cousins with a coffee farm. They are the } \\
\text { family that processes and recycles coffee. }\end{array}$ \\
\hline & &
\end{tabular}

\section{Data Collection and Analysis}

Photographs were taken and selected by students to present to the community. Pictures captured environmental issues such as recycling, pesticide use, harvesting, and polyculture (growing multiple crops on one area), as well as social and economic issues such as brand perception and migrant labor. Images used for the projects did not include people unless written permission was given. As such, data sources included photographs taken and narratives written by the students about their photos and reflections from the community members as well as the students in both classes about the photovoice event. Qualitative data gathered through this research and reported here were analyzed using thematic analysis (Boyatzis, 1998) until researcher consensus was attained. Using thematic analyses, the qualitative data were coded with low inference codes and then layered into families. Then, by describing relations among families as themes, the codes ultimately resulted in the formulation of overarching themes to describe the data.

\section{Validity}

As Carspecken (1996) asserts, the high level of researchers' involvement (here by both teaching and researching the photovoice process) in qualitative inquiry generates concerns about the validity of interpretations. We supported the validity of our descriptions of student and community data by using multiple data sources and a low-inference 
vocabulary (i.e. using students' words as much as possible and drawing inferences mutually agreed upon by all researchers). Judgments about transferability are based on information regarding the investigator, the setting, the methodology, the participants, and the nature of the relationships between the participant and the researcher.

\section{Findings}

Through our analysis, three overarching themes emerged. These themes were: 1) Recognition of Sustainability; 2) Focus on the Local; and 3) Complexity of Branding. Below we provide examples and explain each of these findings with the students' own photovoice narratives and community members' reflections as exemplars.

\section{Recognition of Sustainability}

As the course entitled Environmental Sustainability: Lesson from a Leader implied, students recognized the coffee crop producers as leaders in best practices regarding sustainable development and production (i.e. recycling waste, limited use of pesticides, maintenance of polyculture). In turn, it was evident how important it was to the community members to have this leadership recognized. For example, one student named Britt showcased a picture of a wastewater recycling innovation she had seen on one of the coffee farms. In Britt's discussion with community members, she became aware of several other recycling practices used in the community. The community members told her about how some people recycle the plastic waste from chemical refuse and others described how wood from the local area was used to heat the coffee during production, another form of recycling and reusing materials and resources. Britt commented in her reflection,

Originally looking at my photo and writing the narrative I did not think
there would be many companies that recycle in so many different forms and
didn't know how important is was to the companies. My photo showed the
machine that recycles water until it cannot be used any more. When talking
with the different families, I found that many companies are recycling in
many different ways I hadn't even considered.

Enthusiastic about broadening her understanding of this topic, Britt went on in her reflection to describe the program called Bandera Azul that several community members referenced, which awards coffee producers for their recycling practices. In her reflection, she wrote, "I think this program is a great idea because as it is recognizing the good recycling habits maybe it will urge other companies to practice those habits as well." It was evident in the community discussion resulting from Britt's photograph and narrative how much the community members appreciated her recognition of their positive environmental practices and were excited to contribute to broadening her awareness of other good practices being employed in the area.

Throughout this dialogue on sustainable practices, tensions arose regarding what sustainability actually meant and to whom as well as challenges in maintaining their status as recognized leaders in best practices. For example, several community members agreed it was best not to use pesticides and described alternatives in pest management: Not everyone uses pesticides. Some of us use "chapias" with machetes and that way contamination is avoided (Natalia, lives on a coffee farm with parents). Many of the 
growers emphasized how environmental conditions dictate the growth of the coffee crop, which requires specific growing conditions that will greatly impact the quality of the coffee. For example, several community members referenced how climate change is impacting their crop and need for the use of pesticides. One community member noted that his land was positioned on a low elevation on the mountain and as temperatures in the area rose as they have in the past few years, pests were becoming more of a problem on his land. Though he had not needed to use pesticides before, evolving environmental conditions were now requiring the need for pest management. In this conversation, he attempted to convey how the use of pesticides is complex and not all bad. He explained to the students that the type of pesticide and the treatment of the crop should be considered rather than broadly declaring that any pesticide use is bad for the environment:

In contradiction, some do use pesticides at times, but if they don't the insects will eat the crops. Also some contain minerals that are healthy for you. A lot of farms use natural pesticides that are organic so it doesn't harm the plant (Juan, coffee grower).

Another student's photo and narrative described the polyculture she learned about on the plantation tours. In Karen's narrative, she said:

[On the plantation tours,] I got to learn a lot of new things about the coffee growing process that I did not already know. I've always thought of fruit trees as being used for fruit. Not for protection for other plants. I will hopefully be able to use this at home because I like to grow plants as well.

Similar to the dialogue about recycling, community members were pleased Karen recognized and understood this practice; however, like the tension present in the dialogue about pesticides, they commented on the challenges of maintaining polyculture at some farms depending on their elevation given the changing temperatures induced by climate change. In Karen's reflection, she showed not only her understanding of polyculture, but also her new informed understanding of the challenge of this practice:

The more trees, the more shade and better water distribution from the rain.

But with coffee being higher up, it is colder and harder to grow other fruits.

It's hard to grow banana trees here, because they need shade. But, most of the

fruit trees here are not to produce fruit, but to protect the coffee plants from the sun and rains.

Thus, our data showcased the ways in which community members appreciated the recognition of their leadership in sustainable coffee development and production, but also uncovered the challenges inherent in remaining solvent within a sustainable agriculture system. Many conversations took the form of broadening awareness about these challenges while confirming the recognition of positive environmental practices the students were learning about in class.

\section{Focus on the Local}

Another finding that emerged from our data was the focus on the local. While students' photos and narratives did not directly address local connections, the community members' responses to the photos very palpably illustrated the pride they took in their 
local environment and connection to the land on which they lived. In three out of the eight student photovoice projects, resulting dialogue focused on the intense connection community members had to their land, which was surprising to students. Described below, two examples illuminate this finding-one that focuses on migrant workers and one that focuses on humanitarian initiatives in coffee exportation.

First, one student wished to discuss the migrant farm workers who traveled from Panama and Nicaragua each harvesting season to pick coffee-widely seen as an arduous job with known hazards such as dangerous working conditions, long hours, use of child labor, and low pay. The student, Danielle, talked about her understanding of Mexican immigration and lack of workers' rights in the United States and wondered if migrant workers were treated similarly in Costa Rica. Her picture showed a collection container used by coffee pickers and her narrative focused on the treatment of migrant, seasonal workers and the value most Costa Ricans felt that these workers added to the coffee industry.

She also posed the question in her narrative about what it means to be local, writing "If Panamanian or Nicaraguan workers pick the coffee, is it still 'local'?" Community response to Danielle's photo and narrative was a passionate and resounding affirmation that just because migrants were part of the harvesting process, the product was local. As Luis and Rosa posited,

It doesn't take from the quality of the coffee because even though the workers are from another country, the bean is produced here and that is what matters (Luis, coffee consumer), and

With respect to the benefits of using local laborers, but for the picking of coffee it is necessary to have foreign labor because without it, it couldn't be harvested (Rosa, coffee farm owner).

It was evident how important the local label was to the community and they explained that the land on which they lived was the determining factor in their high quality coffee production and that the product could not be produced without the help of outside laborers. It was a stark reminder of the powerful market forces at play within the Costa Rican coffee industry and the keen awareness of rural coffee producers regarding the desirability and marketability of local products among consumers and the need to qualify for that label.

Furthermore, with regard to migrant workers' rights, many of the community participants explained that they were viewed as an extension of the community and part of the family. Though this characterization of Panamanian migrant workers is a bit simplistic and a tad patronizing, some participants described specific families of workers that would come each year generation after generation, and they knew the individuals well. They also acknowledged the appreciation they had for the workers doing a job that was necessary but that many of them would not want to do,

The fact that the coffee pickers are Panamanian does not affect the local label since in reality they are a great help since the local people don't like to pick coffee (Natalia).

Nevertheless, this sentiment resembles quite strikingly the narrative used in the United States when the topic of Mexican migrant workers is broached. Unfortunately, this sort of discourse may mask deeper issues of prejudice. Danielle was surprised by 
the reaction of the community members' defense of the local label ("Surprisingly, everyone in my conversations said that even though the workers may not be local, that the product is local"). Her reflection of the photovoice experience shown below illustrates how her assumptions were challenged and showcases her new understanding:

Some insisted that the workers are encouraged to pick the coffee as a way to support other neighboring countries who are struggling financially/economically or agriculturally. The feeling that I get from the people was that it's a good thing that workers came because Costa Ricans don't want to do the work; apparently, it's hard, dirty, + dangerous work. Several people compared the situation to the Mexican workers in the US who harvest tobacco. Some perceive it as a stealing of work b/c it's cheaper. However, there seems to be a different attitude in Costa Rica because the people I've spoken to don't see it as a loss or disturbance. In general, the people rejoice in having such an interactive co-op. The people seem to genuinely perceive it as local + are proud for all of its community outreach products, methods, + services it provides.

Second, the theme of focusing on the local arose in two photovoice projects that captured the humanitarian efforts surrounding coffee exports. When students toured the co-op production facility, they took pictures of the placards that were in the entryway describing the outreach efforts of the co-op to benefit surrounding areas in Costa Rica.

One placard described how a portion of proceeds from the coffee went to helping with protection of sea turtle nesting spots and another described the Caritas program, an international and religiously affiliated program that aids children and families. The students were impressed that the co-op included this humanitarian outreach in their mission and wrote narratives expressing the importance for companies to give back to others through these types of environmental stewardship and social welfare programs.

However, community dialogue caused the students to see that there were multiple perspectives about the effectiveness and true benefit of these humanitarian programs. For example, several of the community participants said they were not even aware of these programs despite their direct involvement in the co-op:

We don't know the answer because it has not been made known. This program of the Coope [cooperative] has not been made known to us. We find it interesting (or calls our attention) of this social program, but we would like it to be more publicized in the area (Alonso, family of coffee farmers)

In addition to some community members not knowing about the programs, those who did posed the question as to whether they were truly beneficial to the local area. For example, Yazmin (a self-described coffee consumer) said, "To us it seems there are other animals in the area that also deserve protection and they don't receive it - or even the rivers and other things." Another said:

These prizes are good, but I think it would be better to emphasize it more in the coffee farms in the area in order to help the coffee growers improve their crops. There are two organizations, but they are not very efficient in looking for help (Alexa, family of coffee farmers)

In this exchange, the students realized that there were other perspectives on the humanitarian programs they had not previously considered. In David's reflection, he described these different viewpoints: 


\begin{abstract}
When talking to members of the community, they all liked the fact that the co-op was helping protect the turtles. However, some thought that local animals and coffee farmers should be helped first while others claimed that it was already being done. However, there is another view that even though there are programs in place, they aren't known or effective. These differing viewpoints are interesting because no one had the same thoughts on the issue. Even within the same family, there were debates on the topic about if they existed or if they worked or whether anything more would be done in the future. These different views lead me to believe that more could be done locally to help the farmers as well as other issues.
\end{abstract}

David was surprised at the ensuing debate of the issue and believed there could be resolutions made to direct more of the resources locally. Kylie agreed more could be done and was surprised by the lack of knowledge about the programs

(i.e. "[one participant] seemed visibly upset that us 'gringos' knew something about their area that they didn't"). She said, "It's probably due to a lack of publicity. Inside the tostadoia [sic], there were multiple logos showcasing caritas, but the people don't go in there. They should advertise their donations."

In these discussions about their photos and narrative, both students came to understand the importance the community places on the local label as well as the strong desire for investment in the local economy and natural resources.

\title{
Complexity of Branding
}

Finally, overlapping with the above debate of the effectiveness and benefit of humanitarian programs, a theme emerged regarding the complexity of branding coffee exports with the label of 'fair trade.'

Like the students who focused on the humanitarian programs, the student who did her photovoice project on the fair trade label had positive associations with it. CeCe took her photo at the co-op on our facility tour and wrote her narrative on the importance of giving back to the community. She wrote about how she and her friends always purchased fair trade coffee and other products (despite the elevated cost) and how she understood it to be a program that helped the farmers more directly. She wrote about how neat it was to see the label put on the coffee prior to distribution and meet the producers who actually benefited from this program.

Community responses to CeCe's photo and narrative were varied. Reactions to fair trade showcased the complexity of this label to the actual producers. Many community members questioned the basic premise of fair trade, one stating, "They [distributors] are interested in the price of coffee and the more expensive it is, the less it's consumed" (Juan, coffee grower and member of the co-op). Beyond questioning if fair trade was actually a good idea in an economic sense, many participants felt the program was shrouded in mystery and should be more transparent to members of the co-op. Two coffee growers, Rosa and Ana, stated "I wouldn't know if there was this type of coffee at this Coope" (Rosa) and "The goal would be to know if the grower is informed of the awarding of this seal or certificate" (Ana). Both of these growers went on to say they had never heard of the fair trade seal applied to their coffee and were not aware if it was or was not. They believed this was the case for most growers. 
Overwhelmingly, the majority of community members questioned if the fair trade was really working to benefit farmers. There was a concern that benefits are not equally distributed, "It's not fair because it's not for all the members the same and only some groups benefit" (Natalia). Moreover, Clau (coffee plantation owner and associate of the co-op) asserted it not only is an unevenly distributed benefit, but that the label does not benefit the people of this area in any way ("It's a project that benefits some communities because it's an expensive brand of coffee but the members [of the co-op] don't drink it and it doesn't benefit them at all because they all pay the same price") With the above statements, it was evident most community members did not perceive a local benefit from fair trade.

In fact, much dialogue about CeCe's photo and narrative centered on the notion that fair trade could actually be hurting the people in the community. When asked about CeCe's positive attribution to fair trade in her narrative, Rosa said, "To us, this seems false and it might only be for the benefit of money." The general sense from the community was that fair trade was a program that did not get money back to growers and could actually harm the selling of their coffee due to increased prices. Juan stated, "The problem is that a lot of times what is planned for or what is on paper actually hurts the grower and the worker." A general sense of distrust for those in control of the fair trade program was palpable in the community.

CeCe was surprised at how much dialogue her photovoice project inspired among the community participants. She claimed, "This project was eye opening + really gave me a chance to talk to a community about something that affects their life whether they know it or not." She was specifically taken aback that the farmers themselves did not know if their own produce was labeled as fair trade ("The fact that this group didn't know what fair trade was + they sell coffee to the Co-op is very shocking"). In her reflection about the photovoice event, CeCe went to write:

Another group's response was even more shocking. They told me that they don't use fair trade here + that I was wrong about the Co-op participating in fair trade. This took me by surprise since I got the picture + information during our visit [to the co-op]. I cannot believe that people who do business with the Co-op don't know about the things they participate in.

While CeCe felt she was teaching something to the community members by letting them know about the labeling at the co-op, she learned a great deal about her misconceptions about how fair trade impacted the growers. She came to understand that the benefit might not be as direct as she once thought. Instead, she learned that the function of fair trade, at least in this community, was much more complex.

Another group said that fair trade is not fair because the money never makes it to the workers it's supposed to go to. They said the money only goes to the higher ups. My host family said the money doesn't go to the workers in Costa Rica. But my family said they didn't have health insurance until fair trade (CeCe)

Through this community dialogue, she was able to contextualize some of the information she had learned from her home stays as well as the interactions with other community members. In effect, her project led to a rich and nuanced discussion about the reality of fair trade for this community. 


\section{Discussion Related to the Teaching \& Learning of Science}

Habermas (1984) suggests, "Cognitive development signifies in general the decentration of an egocentric understanding of the world" (p. 69), to exemplify that attempts to limit the self and all its values and biases allows for more freedom in interpreting the world. In this study, students' initial perspectives and understandings of course content, field experiences, and dialogue with community members deepened and were challenged as a result of the photovoice experience. Their participation in putting forth their own views and then allowing those views to be shaped by community members' accounts enabled them to broaden their awareness of social, political, and economic factors that shape coffee agriculture in the community-all of which echo extant literature on the intricacy of coffee production and export (Haight, 2011). While their ideas about migrant workers and fair trade were challenged and their views on pesticide use given changes resulting from climate change were expanded, they were pleased to contribute information about the humanitarian programs associated with coffee of which the community was often not aware.

In turn, community members were appreciative of the acknowledgement of their leadership in sustainable crop development and eager to showcase even more ways in which they employed best practices in their agriculture. As well, their opportunity to clarify and in some cases challenge the ideas about migrant workers and fair trade as not equally beneficial to members of coop was important to them. Rather than not interfacing with study abroad students who visit their community and never knowing if the students understood their community, locals were enthusiastic about having the opportunity to assist students in their understanding of the place.

Community members not only shared their local knowledge, but also learned from the students about social programs connected to their coffee crops and desired to demand change in those programs that could more directly benefit the local area. Indeed, we saw that for students and community members, the photovoice experience 1) allowed for multiple perspectives to dialogue about complex factors in environmental sustainability (i.e. migrant workers, evolving land conditions, branding); 2) Connected students to place through connecting to the people of the place (i.e. leaders in sustainability and importance of local); and 3) Inspired a cross-cultural dialogue that broadened awareness and clarified interpretations (i.e. terms like fair trade, social welfare).

Here, photovoice was useful for the bridging of students' background and interests with the environmental science topics of importance to the community. As well, because photovoice enabled the students to communicate with those in a position of knowledge and in some cases control over the issue in a way that democratized the dialogue, it inspired a deepened sense of understanding of the complex factors that shape a community and its resources.

Photovoice provides a means by which learners can deepen their understanding of environmental sustainability as well as contribute to collective understanding of issues that impact a community. Its multilayered approach to enabling students to voice their perspectives and understandings about issues then confer with community members who most directly influence policies shaping the local area makes learning science within the broader community context meaningful and relevant. Exploring environmental sustainability through community participation reflects a fundamentally different relationship between learners and experts - one that requires sharing of power (Schusler $\&$ Krasny, 2008; Cook \& Quigley, 2013). 
Regardless of whether or not learner's efforts are successful in affecting authentic change in their community, engaging in participatory learning methods such as photovoice can enhance learners' understanding of social, economic, and political systems as they identify opportunities for and obstacles to realizing their vision of environmental health.

With this study, authors provide science teacher educators and others interested in enhancing sustainability education through place-based instruction with the practical applications and theoretical underpinnings of photovoice that could enhance their teaching and research. It is authors' hope that the results of this study will contribute to contemporary conversations about the use of photovoice in the science education arena and beyond to promote discussions about cross-cultural dialogue centering on sustainable issues. As well, authors hope to showcase the importance of dialogue across cultures in learning science, the value of multiple voices in the science community, and the connecting of learners to their immediate place, although it be quite foreign to them personally. In our future efforts, authors would like to follow up with the communities with whom they work to determine the long-term impact of photovoice experiences.

\section{References}

Bencze, J. L., Alsop, S. J., \& Bowen, G. M. (2009). Student-teachers' inquiry-based actions to address socio-scientifc issues. Journal for Activist Science \& Technology Education, 1(2), 105.

Bennett, N. \& Dearden, P. (2013): A picture of change: using photovoice to explore social and environmental change in coastal communities on the Andaman Coast of Thailand. Local Environment: The International Journal of Justice and Sustainability, 1-19.

Berbés-Blázquez, M. (2012). A participatory assessment of ecosystem services and human wellbeing in rural Costa Rica using photo-voice. Environmental Management, 49(4), 862-75.

Boyatzis, R. (1998). Transforming qualitative information: thematic analysis and code development. Thousand Oaks, CA. Sage Publications.

Brunold, A. (2015). Civic education for sustainable development and its consequences for German civic education: Didactics and curricula of higher education. Discourse and Communication for Sustainable Education, 6, 30-49.

Calabrese Barton, A. (2012). Citizen(s') Science. Democracy \& Education, 20(2). Article 12. Retrieved April 1, 2016, from http://democracyeducationjournal.org/home/vol20/iss1/12

Carspecken, P. (1996) Critical ethnography in educational research: A theoretical and practical guide. New York and London: Routledge.

Chinn, P. (2007). Decolonizing methodologies and indigenous knowledge: The role of culture, place and personal experience in professional development. Journal of Research in Science Teaching, 44(9), 1247-1268.

Cook, K. \& Buck, G. (2010). Listening to the learners: Proposing the tool of photovoice for engaging students in community-based socio-scientific inquiry. Science Scope, 33, 35-39.

Cook, K. \& Quigley, C. (2013). Connecting to our community: Utilizing photovoice as a pedagogical tool to connect college students to science. International Journal of Environmental and Science Education, 8(2), 339-357.

Cook, K. (2014). Beginning a classroom inquiry: Using photovoice to connect college students to community science. Journal of College Science Teaching, 43(6), 22-27. 
Downey, L. et al. (2009). Dialogue to deliberation: Expanding the empowerment education model. American Journal of Health Behaviors, 33, 26-36.

Fairclough, N. (2001). Language and Power (2 $2^{\text {nd }}$ ed.). New York: Longman.

Fisher D., Aubrecht, E., Bruck, M., Ditges, L., Gathen, L., Jahns, M., Moritz, P., Rau, J., \& Wellmann, C. (2015). UN global action programme and education for sustainable development: A critical appraisal of the evidence base. Discourse and Communication for Sustainable Education, 6, 5-20.

Freire, P. (1970). Pedagogy of the oppressed. New York: Continuum.

Gruenewald, D. A., \& Smith, G. A. (Eds.). (2008). Place-based education in the global age. New York: Taylor \& Francis.

Habermas, J. (1984). The theory of communicative action volume one: Reason and the rationalization of society. Boston: Beacon Press.

Haight, C. (2011). The problem with fair trade coffee. Stanford Social Innovation Review. Retrieved on June 2, 2015 at: http://www.ssireview.org/articles/entry/the_problem_ with_fair_trade_coffee

Hodson, D. (2003). Time for action: Science education for an alternative future. International Journal of Science Education, 25, 645-670.

Johnson, A.G. (2008). The forest and the trees: sociology as life, practice, and promise. Philadelphia: Temple University Press.

Morgan, M. et al. (2010). Empowering women through photovoice: Women of LaCarpio, Costa Rica. Journal of Ethnographic and Qualitative Research, 5, 31-44.

Nespor, J. (2008). Education and place: a review essay. Educational Theory, 58(4), 475-489.

Powers, M. \& Freedman, D. (2012). Applying a social justice framework to photovoice research on environmental issues: A comprehensive literature review. Critical Social Work, 13, 2, 80-100.

Quigley, C., Dogbey, J., Che, M., \& Hallo, J. (2014). Investigating local sustainable environmental perspectives of Kenyan community members and teachers. Cultural Studies of Science Education, 10, 3, 551-580.

Roth, W.M., \& Lee, S. (2004). Science education as/for participation in the community. Science Education, 88, 263-291.

Sadler, T., Barab, S., Scott, B. (2007). What do students gain by engaging in socioscientific inquiry? Research in Science Education, 37, 371-391.

Schusler, T. \& Krasny, M. (2007). Youth participation in local environmental action: An avenue for science and civic learning? In A. Reid, B. Jensen, J. Nikel and V. Simovska (Eds.), Participation and learning: perspectives on education and the environment, health and sustainability (pp. 268-284). Dordrecht: Springer.

Sobel, D. (2005). Place based education: Connecting classrooms and communities (2nd edition). Great Barrington. MA: The Orien Society.

Tippins, D.J., \& Mueller, M.P. (2010). Questions for Copenhagen: EcoJustice perspectives and summary. In D. Tippins, M. Mueller, M. van Eijck \& J.D. Adams (Eds.), Cultural studies and environmentalism: The confluence of EcoJustice, Place-based (science) education, and indigenous knowledge systems (pp. 181-184). New York: Springer.

Wang, C. \& Burris, M. (1994). Empowerment through photo novella: portraits of participation. Health Education Quarterly, 21, 171-186.

Wang, C. (2005). Youth participation in photovoice as a strategy for community change. Journal of Community Practice, 14, 147-161. 
Zeidler, D.L., Sadler, T.D., Simmons, M.L., Howes, E.V. (2005). Beyond STS: A researchbased framework for socio-scientific issues in education. Science Education, 89, 357-377.

Correspondence concerning this article should be addressed to Dr. Kristin Cook, Faculty of Science Education at Bellarmine University, Louisville, KY, USA. Email: kcook@bellarmine.edu

\section{Appendix A}

\section{Translation of Reflection from Photovoice Participant}

Por favor describe su relación con el café. Mujer 22 años.

que desde que era pequeña me relacione con este producto, puesto tenía que acompañar a mi papá para la recolección del cultivo. Hoy día yano lo recolecto pero es mi bebida favoxita.

A) Los diversos cultivos son muy importantes tanto por que puede generar nuevos productos para la finca, como por que siryen de hogar para los pajaritos yotros animales que viven en la finca, al igual que es importante por que sirve de sombra para el café.

B) El programa caritas es muy importante porque gracias a esto es B) que ahora es más facil congegir cafel de coopetarracú en cualquier parte del pais. C) La responsabilidad social es un tema sumamente importante manera en la zona. Es de especial importanceremar que el tema de las tortugas baulas deberia implementarse mós, involucrando

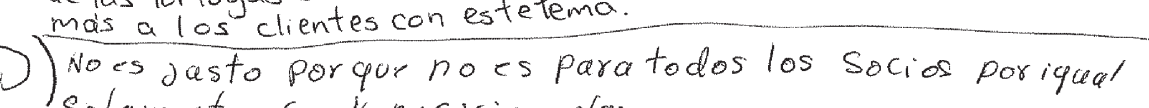
solamente. Se bene Eicicen algunos grapos.

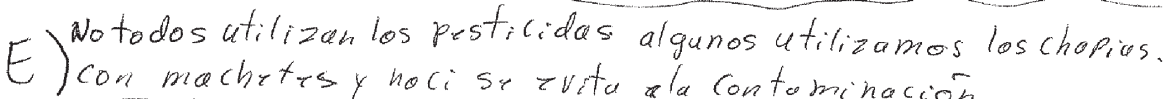
con machetes y hocise zuita a la contominación F) i todos tratan de montener todo en orden

(1) Que los recolectores de café sean Panameños no afectan en 7) las pricticas sostenibles, ni en que sea "lo cal" puesto que locales no les gusta mucho recolectar que las personas 
Please describe your relationship with coffee.

Woman, 22 years old.

My parents have coffee farms, so since I was a little girl, I've had a relationship with this product since I had to accompany my father to pick coffee. Now, I do not pick it but it is my favorite drink.

Comments on Photovoice Narratives:

A) The different crops are very important not only because they generate new products (crops) for the farm, but they also provide a home for different animals that live on the farm and they are also important to provide shade for coffee.

B) The Caritas program is very important because thanks to this program, it is now easier to get CoopeTerrazu coffee in any part of the country.

C) Social responsibility is a very important topic and it would be great if it were truly implemented in a better way in this area. It is especially important to re-visitthe topic of the Baula turtles and involve the customers more with this issue.

D) It's not fair because it's not the same for all the members and only some groups benefit.

E) Not everyone uses pesticides. Some of us use "chapias" with machetes and that way contamination is avoided.

F) Yes, everyone tries to keep everything in order by recycling

$G)$ The fact that the coffee pickers are Panamanian does not affect sustainable practices, nor the local label since in reality they are a great help since the local people don't like to pick coffee. 